\title{
Effect of coding activities on preschool children's mathematical reasoning skills
}

\author{
Büşra Somuncu ${ }^{1}\left[\right.$ D $\cdot$ Durmuş Aslan ${ }^{2}$ (1)
}

Received: 18 April 2021 / Accepted: 1 June 2021 / Published online: 1 July 2021

(c) The Author(s), under exclusive licence to Springer Science+Business Media, LLC, part of Springer Nature 2021

\begin{abstract}
The present study was conducted to investigate the effect of coding activities on children's mathematical reasoning skills. In the study, the pre-test - post-test control group quasi-experimental design was used. The participants of the study consisted of 29 children (17 in experiment group and 12 in control group) aged between 57 68 months attending a public kindergarten in Adana, Turkey. Coding Education Program prepared by the researchers was administered to the children in the experiment group while the children in the control group received the regular program. Evaluation Instrument for the Early Mathematical Reasoning Skills was administered to children both in the experimental and control group as pre-test and post-test. Data was collected by individual interviews conducted with the children. Results of the study showed that there is no significant difference between experimental and control group in the pre-test, whereas a significant difference in favor of the experimental group was observed in the post-test. Therefore, it was determined that the coding activities have a significant effect on mathematical reasoning skills of children.
\end{abstract}

Keywords Coding activities - Programmable toy - Early childhood education · Mathematical reasoning

\section{Introduction}

Early childhood education is expected to enable children to form some basic social and cognitive skills which they will need in the forthcoming years in addition to helping them adapt to social life (Demetriou et al., 2017). One of these basic skills

Büşra Somuncu

busrasomuncu@gmail.com

Durmuş Aslan

durmaslan@gmail.com

1 Department of Early Childhood Education, Anadolu University, Eskisehir, Turkey

2 Department of Early Childhood Education, Cukurova University, Adana, Turkey 
is mathematical reasoning. Henderson et al. (2001) define mathematical reasoning as the mathematical ways of thinking that is required to solve problems in any field. Reasoning skill is considered to be the foundation of mathematical competence and lack of it can cause disruptions in mathematics education (Keazer \& Menon, 2016). Due to the fact that reasoning constitutes the basis of all rules and operations in mathematics, mathematical reasoning skill is considered to be the building block of mathematics (Umay, 2003; Umay \& Kaf, 2005).

It is generally expected that skills such as comprehending the connection between events, reasoning and deduction to be shaped during early childhood period (Altıparmak \& Öziş, 2005). For this reason, early childhood mathematics programs should introduce rich experiences with regards to these skills to children. Helping children to understand that their arguments always need to have a reason through these experiences is very important for developing the reasoning skills (National Council of Teacher of Mathematics [NCTM], 2000). Moreover, these experiences hold importance in terms of children developing a positive attitude towards mathematics once they encounter formal mathematical education in the coming years (Aktaş Arnas, 2012; Erdoğan \& Baran, 2005; Henniger, 1987). Therefore, early childhood mathematics programs need to make the mathematics education fun, beneficial, easy and useful. Attention needs to be paid that the content of the prepared programs are rich and they provide suitable environment and materials for children to discover the basic concepts (Bağcı \& İvrendi, 2016).

Using mathematics or reasoning about mathematical situations are closely related to mathematical knowledge and being familiar with the mathematical concepts (Mullis et al., 2005). Individuals who understand and implement mathematics will have important opportunities and options on shaping their futures (NCTM, 2000). Despite the fact that mathematics is a field of science based on numbers and measurement, its priority is not only formulate the numbers and perform calculations based on memorization. At the same time, mathematics is a way of thinking and questioning (Paulos, 1995). In early childhood, children need support to formulate and solve problems as well as thinking on reasoning strategies. Whittaker (2014) states that children begin to develop their reasoning skills from early age and that these skills constitute effective support for their later development and learning. Children with mathematical reasoning skills will make better sense of the world they live in and the mathematical ideas with which they are presented. By this manner, children will gradually become more competent in understanding and analyzing mathematics around them (National Research Council, 2009). In order to develop the reasoning skills of young children, it is necessary to highlight the different characteristics of the objects and to encourage them to ask various questions (Keazer \& Menon, 2016; Rule, 2007). When teachers provide the children an environment rich with stimuli and promote the interaction between children, they will also support their reasoning and problem-solving skills (Henningsen \& Stein, 1997; Whittaker, 2014).

Coding activities are efficient instruments that teachers can use in order to enrich the learning experience of children. Recently, there is a growing interest in the field of early childhood education with regards to digital competence area, including coding skills. Programming, in other words coding, which improves 
reasoning skills and thus is likely to support mathematical reasoning skills, has become a popular field which is widely taught in schools in recent years (Heikkilä, 2020; Toh et al., 2016). Coding is an activity that combines the concepts of problem solving and reasoning in its core because the program to be written is a problem to be solved by using the computer as a tool. Due to this, coding activities provide students with a highly sustainable engagement in problem solving and reasoning (Fox \& Farmer, 2011). By virtue of coding education, children are provided with an opportunity to transform their ideas into products. Consequently, children obtain the necessary motivation to learn about computer science more in detail. Moreover, children are able to create solutions to existing problems by using coding in addition to their creativity and imagination (Çankaya et al., 2017).

Mathematics activities that are prepared for children in early childhood should have qualities to enable them to learn by experience and to discover mathematics by way of trial and error and games (Aktaş Arnas, 2012; Perry \& Dockett, 2008). Accordingly, coding activities are tools which enable children to learn skills such as problem solving and reasoning through experience. In addition, coding activities create a learning environment that encourages children to interact with each other, to learn by playing and to play while learning (Bers, 2008a; Resnick, 2003). Children can comprehend some of the abstract rules and concepts in the fields of science and mathematics via the products they create by coding (Morgado et al., 2010). When all of these aspects are considered as a whole, it can be said that mathematical reasoning skill and coding education contribute to each other. Previous studies showed that coding education is a tool with positive influence on children especially in terms of high cognitive skills including mathematical skills, reasoning and problem solving (Bers, 2008b; Clements et al., 2001; Flannery \& Bers, 2013; Psycharis \& Kallia, 2017; Toh et al., 2016). Although limited in number, there are studies showing that coding education improves children's mathematical reasoning skills as well (Olteanu, 2020; Psycharis \& Kallia, 2017). Nonetheless, these studies were conducted with middle school and high school students. In the literature search, a study investigating the effect of coding activities on mathematical reasoning skills of young children was not found. On the other hand, when the studies conducted in the respective area are evaluated, it was seen that the coding activities and instruments open the way for young children to improving their skills regarding scientific and mathematical concepts and problem solving as well as their social skills (Fessakis et al., 2013; Highfield, 2010; Turan \& Aydoğdu, 2020). The present study was conducted to investigate the effect of coding activities on mathematical reasoning skills in preschool children. In the study, following questions were asked within the scope of this aim:

1. Is there a significant difference between the mathematical reasoning pre-test scores of the experimental and control groups?

2. Is there a significant difference between the mathematical reasoning post-test scores of the experimental and control groups? 


\section{Method}

\subsection{Participants}

Participants consisted of 29 children attending a public kindergarten in Cukurova district in Adana, Turkey. Cukurova is one of the four central districts of Adana city. There are 39 public kindergartens in this district. For sampling, firstly, the public kindergartens in the Cukurova were listed and one was chosen randomly. Afterwards, one of the 4 classes in the chosen kindergarten was randomly assigned as the experimental group and the other as the control group. There were 17 children ( 9 female, 8 male; mean age: 63 months; age range: 58-68 months) in the experimental group, whereas there were 12 children ( 6 female, 6 male; mean age: 62 months; age range: 58-68 months) in the control group. Both groups were composed of children with middle and lower class background. Majority of the parents were high-school or university graduates. Turkish National Preschool Program was being implemented in the kindergarten where the sample was created.

\subsection{Data collection tools}

As data collection tools, a demographical information form created by the researchers was used to collect demographical information of children and their parents, and "Evaluation Instrument for the Early Mathematical Reasoning Skills" by Ergül (2014) was used to assess the mathematical reasoning skills of children.

Evaluation Instrument for the Early Mathematical Reasoning Skills is comprised of 40 questions. 21 of the questions in the evaluation instrument are created to evaluate the measurement skill, while 19 are created to evaluate data analysis and probability skills. In the said evaluation instrument, there are 21 questions regarding the inductive reasoning skills and 19 questions regarding deductive reasoning skills. 9 of the questions are administered to children by using various materials such as ropes of different lengths, shapes made of felt, ping-pong balls, boxes of different volumes; 28 of the questions are administered by using pictures and 3 questions are administered verbally, without using any materials. Children's responses are recorded to grading key. Regarding each item in the Evaluation Instrument for the Early Mathematical Reasoning Skills, correct and complete explanations are scored "5", correct but incomplete explanations are scored "4", no explanation or unrelated explanations are scored " 3 ", false explanations are scored "2", and meaningless explanations or lack of explanations are scored " 1 " and no interest is scored as " 0 ". The lowest score that can be obtained in the evaluation tool 0 is and the highest score is 200 .

Results of the item analysis, which was conducted by Ergül (2014) with the purpose of assessing the proficiency of the evaluation tool in differentiating children in terms of the measured characteristics, showed that the evaluation tool is qualified in distinguishing children with low and high level mathematical reasoning skills. Krippendorff Alfa coefficients of the evaluation tool were examined and it was seen 
that compatibility average among the coders had been an acceptable value of 0.91 for all questions in the tool. Test-retest reliability of the evaluation tool had been above 0.98 for all fields. In line with this information, it was stated that the Evaluation Instrument for the Early Mathematical Reasoning Skills was a valid and reliable assessment tool (Ergül, 2014).

\subsection{Data collection}

Coding education program Coding education program has been prepared by the researchers with the purpose of supporting mathematical reasoning skills of children. In the first phase of the program development, a literature review was performed and target skills were determined. Afterwards, 20 mathematics activities including the determined target skills were planned. Expert opinions regarding the prepared program were obtained from 5 academicians working in the field of early childhood mathematics education. The final version of the program was created by organizing activities in line with the opinions and recommendations of the experts. Activities included in the Coding Education Program are given in Table 1.

The first four activities of the coding education program are composed of activities that are created by implementing the unplugged coding method. It is aimed that

Table 1 Coding activities

\begin{tabular}{|c|c|c|}
\hline Activity Name & Activity Type & Target Skill \\
\hline Code-it & Large group activity & \multirow{4}{*}{$\begin{array}{l}\text { Introduction to coding via activities with no } \\
\text { programming material (unplugged coding } \\
\text { activities) }\end{array}$} \\
\hline Code Parkour & Large group activity & \\
\hline Coding My Friend & Large group activity & \\
\hline Robi the Frog & Small group activity & \\
\hline Neighborhood Walk & Small group activity & \multirow{3}{*}{$\begin{array}{l}\text { Familiarization with the material and mapping } \\
\text { activities }\end{array}$} \\
\hline Robi is Mapping & Small group activity & \\
\hline Lost Items & Small group activity & \\
\hline Which Path? & Small group activity & \multirow[t]{3}{*}{ Measuring activities with non-standard units } \\
\hline My Robot Measures & Large group activity & \\
\hline Measuring with Blocks & Small group activity & \\
\hline Robot Robi's Friend & Small group activity & \multirow[t]{2}{*}{ Sequencing time activities } \\
\hline Dining Table & Small group activity & \\
\hline Shopping List & Small group activity & \multirow{2}{*}{$\begin{array}{l}\text { Activities to understand the accuracy of the } \\
\text { obtained results }\end{array}$} \\
\hline Noah's Pudding of the Neighbor & Small group activity & \\
\hline Robot Robi's Balloon & Small group activity & Estimation and probability activities \\
\hline Do the Same & Small group activity & \multirow[t]{3}{*}{ Activities of knowing the properties of shapes } \\
\hline Stick Shapes & Small group activity & \\
\hline Stones in the River & Small group activity & \\
\hline Cookies in the Jar & Small group activity & \multirow[t]{2}{*}{ Graphic creation and reading activities } \\
\hline Let's find the bricks & Small group activity & \\
\hline
\end{tabular}




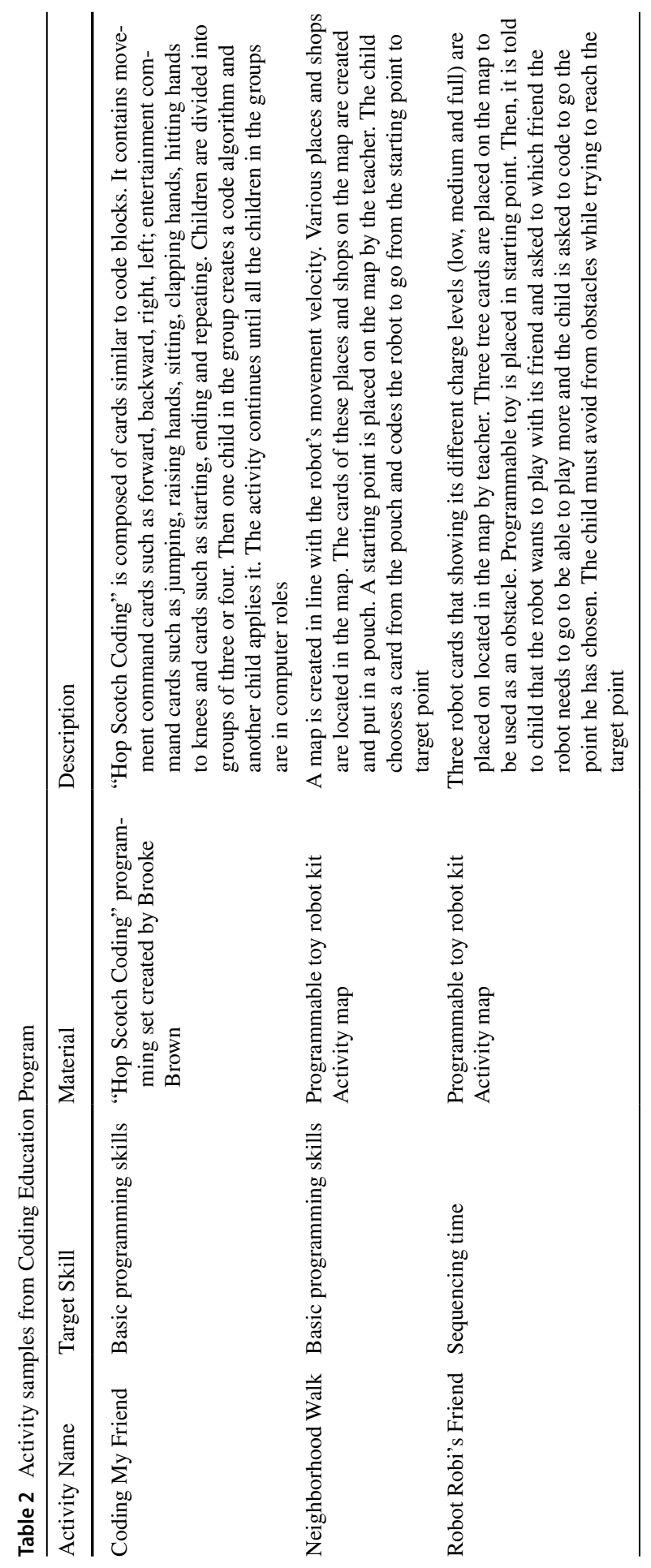


children are introduced to programming via these activities to learn basic components of programming. The purpose is that children can implement programming strategies on the material and use more advanced languages after completing these activities. In the following activities, a programmable toy robot named Bee-Bot, one of the tangible programming tools, was used. This toy robot has been chosen for its ease of use and appeal to young children.

Examples of activities in the Coding Education Program are given in Table 2. Each activity of the coding education addresses a different mathematical reasoning skill; and it was aimed that the children gain these skills through computer programming activities. All activities were implemented in the classroom (Figs. 1 and 2).

Implementation of the evaluation instrument As a first step in the data collection process, consent forms were received from the school where the implementation will take place and from the parents of children who will participate in the study. Afterwards, Evaluation Instrument for the Early Mathematical Reasoning Skills was applied to children both in the experimental and control groups as pre-test with individual interviews. Once the pre-test phase is completed, one of the researchers administered the Coding Education Program to children in experimental group. The program was conducted 4 days a week for 5 weeks. Children in the experimental group have continued their regular program when the coding activities were not being implemented. With the termination of the coding program, Evaluation Instrument for the Early Mathematical Reasoning Skills was implemented as post-test both for the experimental and control groups. It was originally planned to implement a retention test 4 weeks after the post-test phase, however, it was not possible to be administer the retention test due to interruption of face-to-face education because of Covid-19 pandemic.

Fig. 1 Child participating the hop scotch coding activity

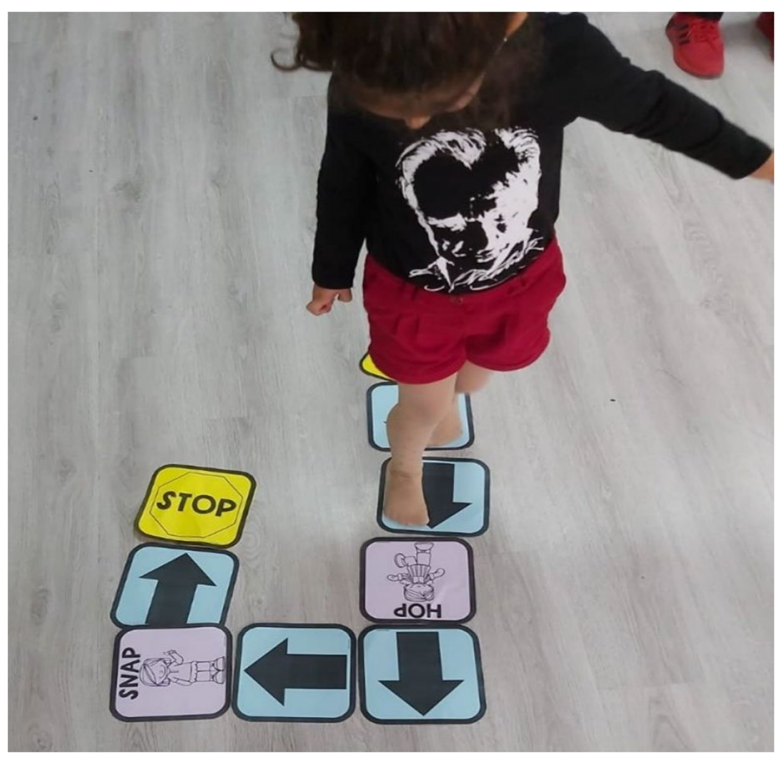



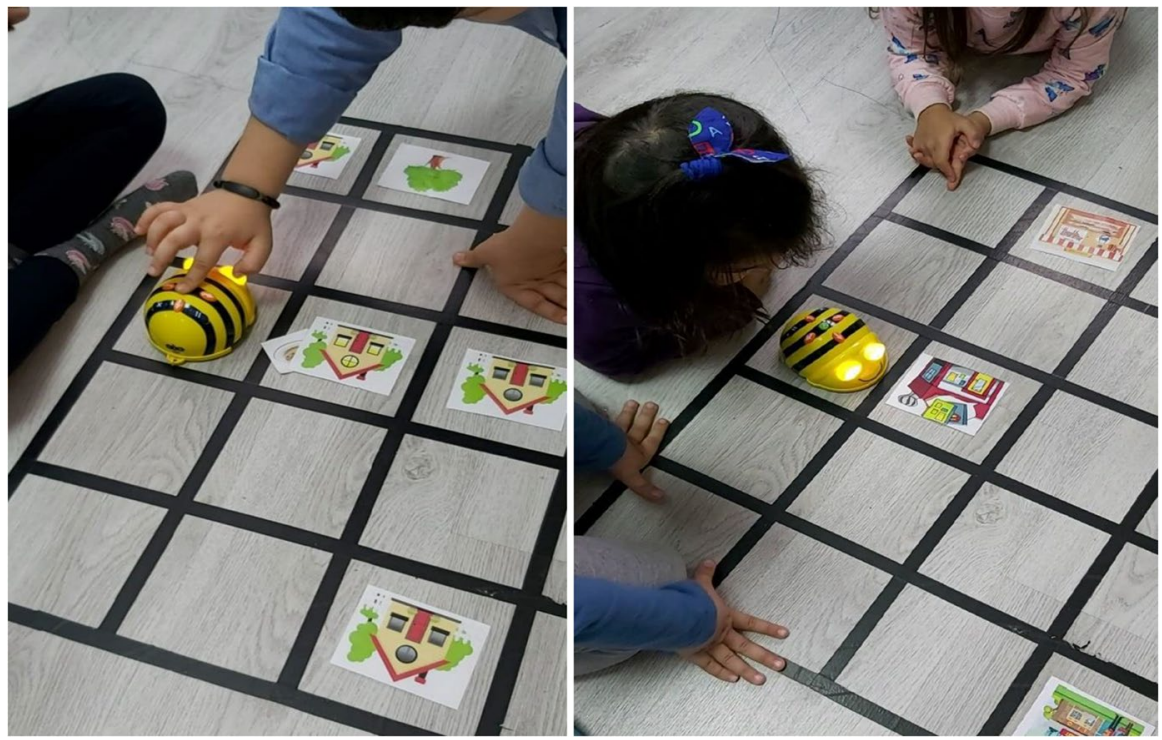

Fig. 2 Children participating the Noah's pudding of the neighbor and the neighborhood walk activities

\subsection{Data analysis}

Scores obtained in Evaluation Instrument for the Early Mathematical Reasoning Skills were analyzed according to descriptive statistics and normality test results. Shapiro-wilk Test result revealed that pre-test and post-test scores of experimental and control groups were normally distributed $(\mathrm{p}>0.05)$. Therefore, parametric tests were used in the data analysis. An independent sample t-test was performed in order to determine whether there is a significant difference between the pre-test scores of experimental and control groups. Additionally, a paired sample t-test was conducted to determine whether there is a significant difference between the pre-test and post-test scores for both groups. Finally, a covariance analysis (ANCOVA) was performed in order to compare the post-test scores of both groups by controlling for pre-test scores.

\subsection{Ethical issues}

This study was carried out after obtaining the necessary legal permissions from Adana Provincial Directorate of National Education. Then, the necessary information about the research was given to the administrators and teachers of the school where the intervention study would be conducted, and permission was obtained for the research. Afterwards, a detailed information letter about the purpose of the research and the research process and a parent consent form were given to the parents. The children who will be included in the research were determined with the feedback from the parents. During the data collection process, the researcher took care that the implementation of evaluation instrument was not during an activity that the children enjoyed. The implementation was recessed in cases such as distraction of the children and their need for toilet and water. 
Table 3 Descriptive statistics for the pre-test and post-test

\begin{tabular}{|c|c|c|c|c|c|c|c|c|c|}
\hline \multirow[b]{2}{*}{ Group } & \multirow[b]{2}{*}{$\mathrm{N}$} & \multicolumn{4}{|l|}{ Pre-test } & \multicolumn{4}{|c|}{ Post-test } \\
\hline & & $\overline{\mathrm{x}}$ & SD & Min & Max & $\overline{\mathrm{x}}$ & SD & Min & Max \\
\hline Experimental & 17 & 103.17 & 9.35 & 85 & 119 & 112.76 & 8.25 & 98 & 124 \\
\hline Control & 12 & 103.16 & 7.40 & 91 & 117 & 106.58 & 5.88 & 95 & 117 \\
\hline
\end{tabular}

\section{Results}

The present study was conducted to investigate the effect of coding activities on mathematical reasoning skills in preschool children. In this section, analysis results of pre-test and post-test scores are presented. Descriptive statistics for pre-test and post-test scores of experimental and control groups are given in Table 3.

The mean of experimental group was 103.17 in pre-test and 112.76 in post-test, while the mean of control group was 103.16 in pre-test, and 106.58 in post-test. An independent sample t-test was performed to determine whether there is a significant difference between the experimental and control groups in pre-test. T-test analysis results revealed that there is not a statistically significant difference between the pretest scores of the two groups $(\mathrm{t}(27)=0.003, \mathrm{p}>0.05)$. Therefore, it was determined that mathematical reasoning scores of both groups have been similar before the intervention. At the same time, paired sample t-test was performed to compare the pre-test and post-test scores of both groups. The results of the analysis revealed that there is a statistically significant difference between the pre-test and post-test scores of the experimental group $(\mathrm{t}(28)=-7.21, \mathrm{p}=0.001)$. A statistically significant difference was observed between the pre-test and post-test scores of the control group as well $(\mathrm{t}(11)=-3.09, \mathrm{p}=0.001)$. Therefore, results showed that scores of both groups have risen in the post-test in comparison to the pre-test scores. Thus, a covariance analysis (ANCOVA) was performed by controlling for the pre-test scores in order to compare the post-test scores of both groups. Table 4 demonstrates ANCOVA results for the effect of the coding activities on children's mathematical reasoning skills.

ANCOVA analysis result showed that there is a statistically significant difference between the two groups in favor of the experimental group regarding the mathematical reasoning skills $\left(\mathrm{F}(1,26)=18.827 ; \mathrm{p}=0.001 ; \eta^{2}=0.420\right)$. It was determined that the effect size of the implemented intervention program on the mathematical reasoning skills of children was medium level.

Table 4 ANCOVA results for the effect of the coding activities on mathematical reasoning skills

\begin{tabular}{lcccccc}
\hline Source of variance & Sum of squares & df & Mean of square & F & p & $\eta^{2}$ \\
\hline Pretest & 1099.654 & 1 & 1099.654 & 77.206 & .001 & .748 \\
Group & 268.152 & 1 & 268.152 & 18.827 & .001 & .420 \\
Error & 370.322 & 26 & 14.243 & & & \\
Adjusted total & 1738.759 & 28 & & & & \\
\hline
\end{tabular}




\section{Discussion}

The findings of the study showed that there is not a significant difference between pre-test scores of experimental and control groups, while there is a significant difference in post-test results in favor of the experimental group. Therefore, it is seen that coding activities improve children's early mathematical reasoning skills. Previous studies about computer programming, namely coding, generally focused on problem solving skills (Çiftçi \& Bildiren, 2020; Dalton \& Goodrum, 1991; Fessakis et al., 2013; Highfield et al., 2008; Nance, 2016; Yünkül et al., 2017), development of mathematical concepts (Highfield, 2010; Kazakoff et al., 2013; Kynigos, 1993) and cognitive thinking abilities (Bers et al., 2014; Taylor et al., 2010). Results of these studies showed that coding activities have a positive effect on children's problem-solving skills, mathematical concept development and cognitive thinking skills. For instance, Highfield et al. (2008) observed that activities performed with Bee-Bot support children's development regarding mathematical concepts such as transformation and measurement. Bers et al. (2014) determined that after implementation of a program including activities of making and programming robots with children, computational thinking skills of children are improved and that programmable toy robots can be beneficial in strengthening the prerequisites of learning. Kazakoff et al. (2013) assessed children's sequencing skills after an intensive oneweek coding workshop and they found a positive improvement in sequencing skills of children in comparison with pre-workshop status. Taylor et al. (2010) determined that use of Scratch can improve complex computational thinking in children who are determined to have low level of mathematical understanding. As a result, it is seen that coding activities and tools are efficient in enabling children gain mathematical skills.

The findings of the current study also suggest that mathematical reasoning skills can be improved in early period. Similarly, previous studies (Bruder, 2016; Doğan \& Tecimer, 2019; Göncü, 2020; Hallumoğlu, 2019) have shown that mathematical reasoning skills of young children can be supported via appropriate interventions. For example, Bruder (2016) found in a study conducted with children in primary school second grade that keeping an electronic mathematics diary improves students' ability of communicating their mathematical reasoning. Doğan and Tecimer (2019) concluded in an intervention study conducted with pre-school children that music activities that are supported with piano contribute to the mathematical reasoning skills of children. Göncü (2020) concluded that activities that improve estimation skills have a positive effect on children's reasoning skills. Hallumoğlu (2019) found that administering individual and cooperative mathematics activities that are supported with Montessori materials to pre-school children supports children's mathematical reasoning skills. Results of the present study expanded the previous results showing that mathematical reasoning skills can be improved in early childhood via appropriate methods.

Coding Education Program that is used in the present study has been developed with the purpose of supporting children's mathematical reasoning skills by using their coding skills. The program include activities such as estimation, problem 
solving, creating graphs, measurement, testing and knowing the properties of shapes to support mathematical reasoning skills. Results that are obtained in the present study show that materials that are used in the prepared program contribute to children's mathematical reasoning skills. In line with the results of the present study, previous studies has shown that mathematical reasoning skill can be improved via various interventions including above-mentioned activities. For instance, Pilten (2008) found in a study conducted with fifth grade students that metacognition strategies that are used during the problem-solving process in mathematics class are efficient in improving students' mathematical reasoning skills. Kasmer and Kim (2011) showed that use of estimation has a positive effect on conceptual comprehension and mathematical reasoning skills in seventh grade students. Fisch et al. (2011) concluded in a study conducted with pre-school children that educative online games support the mathematical reasoning skills in children. Studies that are conducted with high-school students revealed that computer programming improves reasoning skills (Fox \& Farmer, 2011; Psycharis \& Kallia, 2017).

\section{Conclusion}

The present study was conducted with the purpose of investigating the effect of coding activities on mathematical reasoning skills in pre-school children. Study results show that there is not a statistically significant difference between the pre-test scores of experimental and control groups in terms of mathematical reasoning skills, whereas a statistically significant difference was found between the two groups in post-test scores with regards to reasoning skills. It is observed that mathematical reasoning scores of children in the experimental group has significantly increased in comparison with the children in the control group.

Findings of the present study show that coding activities that are performed with a programmable toy robot contribute to improvement of children's mathematical reasoning skills. This particular result suggests that it is possible to improve children's mathematical reasoning skills via use of various materials and appropriate activities. Moreover, the results expand the scope of the previous findings stating that mathematical reasoning skills can be improved in early stages of childhood. As a result, coding activities and tools are appropriate tools that can be used for contributing to this development.

In the light of the findings of the study, we suggest that teachers prepare and implement in-class activities that aim to support children's mathematical reasoning skills. In addition, parents may present their children digital applications that support children's reasoning skills while coding. In future studies, the effect of coding activities on children's mathematical reasoning skills can be investigated longitudinally. In addition, effects of intervention studies with regards to coding can be examined more in detail by using qualitative data.

This research have some limitations that should be mentioned about. First, this study focused on children at one preschool in Adana, Turkey. Future studies could focused on preschool children at different cultures. Secondly this study limited with only 29 children that attend preschool education. Different results may be obtained 
when similar interventions studies with various age groups and different sample size. Lastly, because of the interruption of face-to-face education due to the Covid19 pandemic outbreak, a retention test could not be applied after the intervention program.

Availability of data and material The datasets used and analysed in the current study are available from the first author on reasonable request.

\section{Declarations}

Conflicts of interest The authors have no conflicts of interest related to this work.

\section{References}

Aktaş Arnas, Y. (2012). Okul öncesi dönemde matematik ĕ̆itimi. Ankara: Vize yayıncılık.

Altıparmak, K., \& Öziş, T. (2005). Matematiksel ispat ve matematiksel muhakemenin gelişimi üzerine bir inceleme. Ege Eğitim Dergisi, 6(1), 25-37.

Bağc1, B., \& İvrendi, A. (2016). Türkiye'de okul öncesi dönem matematik becerileri ve eğitimi araştırmaları: Sentez çalışması. Necatibey Eğitim Fakültesi Elektronik Fen ve Matematik Ĕgitimi Dergisi, 10(2), 391-424. https://doi.org/10.17522/balikesirnef.278430

Bers, M. U. (2008a). Blocks, robots and computers: Learning about technology in early childhood. Teacher's College Press.

Bers, M. U. (2008b). Engineers and storytellers using robotic manipulatives to develop technological fluency in early childhood. In O. N. Saracho \& B. Spodek (Eds.), Contemporary perspectives on science and technology in early childhood education (pp. 105-125). Information Age Publishing.

Bers, M. U., Flannery, L., Kazakoff, E. R., \& Sullivan, A. (2014). Computational thinking and tinkering: Exploration of an early childhood robotics curriculum. Computers \& Education, 72, 145-157. https://doi.org/10.1016/j.compedu.2013.10.020

Bruder, M. (2016). How will electronic journaling influence children's mathematical reasoning and communication? In J. K. Dowdy \& Y. Gao (Eds.), Pump it up: Literacy activities for the classroom (pp. 117-119). Sense Publishers.

Clements, D. H., Battista, M. T., \& Sarama, J. (2001). Logo and geometry. Journal for Research in Mathematics Education, Monograph, 10, i-177. https://doi.org/10.2307/749924

Çankaya, S., Durak, G., \& Yünkül, E. (2017). Robotlarla programlama eğitimi: Öğrencilerin deneyimlerinin ve görüşlerinin incelenmesi. Turkish Online Journal of Qualitative Inquiry, 8(4), 428-445. https://hdl.handle.net/20.500.12462/3587

Çiftci, S., \& Bildiren, A. (2020). The effect of coding courses on the cognitive abilities and problemsolving skills of preschool children. Computer Science Education, 30(1), 3-21. https://doi.org/10. 1080/08993408.2019.1696169

Dalton, D. W., \& Goodrum, D. A. (1991). The effects of computer programming on problem-solving skills and attitudes. Journal of Educational Computing Research, 7(4), 483-506. https://doi.org/ 10.2190/762v-kv6t-d3d1-kdy2

Demetriou, A., Merrell, C., \& Tymms, P. (2017). Mapping and predicting literacy and reasoning skills from early to later primary school. Learning and Individual Differences, 54, 217-225. https:// doi.org/10.1016/j.lindif.2017.01.023

Doğan, C., \& Tecimer, B. (2019). Anasınıfına devam eden çocukların matematiksel akıl yürütme becerilerine piyano destekli müzik etkinliklerinin etkisi. e-Kafkas Ĕ̆itim Araştırmaları Dergisi, 6(3), 13-33. https://doi.org/10.30900/kafkasegt.617233

Erdoğan, S. Ç., \& Baran, G. (2005). Erken çocukluk döneminde matematik. Ĕ̆itim Ve Bilim, 28(130), $32-40$. 
Ergül, A. (2014). Erken matematiksel akıl yürütme becerileri değerlendirme aracı geliştirilmesi. [Unpublished doctoral dissertation]. Hacettepe University.

Fessakis, G., Gouli, E., \& Mavroudi, E. (2013). Problem solving by 5-6 years old kindergarten children in a computer programming environment: A case study. Computers \& Education, 63, 87-97. https://doi.org/10.1016/j.compedu.2012.11.016

Fisch, S. M., Lesh, R., Motoki, E., Crespo, S., \& Melfi, V. (2011). Children's mathematical reasoning in online games: Can datamining reveal strategic thinking? Child Development Perspectives, 5(2), 88-92. https://doi.org/10.1111/j.1750-8606.2011.00161.x

Flannery, L. P., \& Bers, M. U. (2013). Let's dance the "robot hokey-pokey!" children's programming approaches and achievement throughout early cognitive development. Journal of Research on Technology in Education, 46(1), 81-101. https://doi.org/10.1080/15391523.2013.10782614

Fox, R. W., \& Farmer, M. E. (2011). The effect of computer programming education on the reasoning skills of high school students. In H. R. Arabnia, V. A. Clinsy, \& L. Deligiannidis (Eds.), Proceedings of the international conference on frontiers in education: Computer science and computer engineering (FECS'11), (pp. 187-193). USA: CSREA Press.

Göncü, H. B. (2020). Tahmin becerilerinin geliştirilmesinin 60-72 aylık çocukların akıl yürütme ve sezgisel matematik yeteneklerine etkisi. (Unpublished master's thesis). Marmara University, İstanbul.

Hallumoğlu, K. Ö. (2019). Montessori materyalleri destekli bireysel ve işbirlikli matematik etkinliklerinin erken matematiksel akıl yürütme becerilerine etkisi. (Unpublished Master's thesis). Kırklareli University, Kırklareli.

Heikkilä, M. (2020). What happens when the robot gets eyelashes? Gender perspective on programming in preschool. In A. MacDonald, L. Danaia, \& S. Murphy (Eds), STEM education across the learning continuum (pp. 29-44). Singapore: Springer Nature Singapore.

Henderson, P. B., Baldwin, D., Dasigi, V., Dupras, M., Fritz, J., Ginat, D., Goelman, D., Hamer, J., Hitchner, L., Lloyd, W., \& Marrion, B., Riedesel, C., Walker, H. (2001). Striving for mathematical thinking. ACM SIGCSE Bulletin, 33(4), 114-124. https://doi.org/10.1145/572133.572136

Henniger, M. L. (1987). Learning mathematics and science through play. Childhood Education, 63(3), 167-171. https://doi.org/10.1080/00094056.1987.10520781

Henningsen, M., \& Stein, M. K. (1997). Mathematical tasks and student cognition: Classroom-based factors that support and inhibit high-level mathematical thinking and reasoning. Journal for Research in Mathematics Education, 28(5), 524-549. https://doi.org/10.5951/jresematheduc.28.5.0524

Highfield, K. (2010). Robotic toys as a catalyst for mathematical problem solving. Australian Primary Mathematics Classroom, 15(2), 22-27.

Highfield, K., Mulligan, J., \& Hedberg, J. (2008). Early mathematics learning through exploration with programmable toys. In O. Figueras, J. L. Cortina, S. Alatorre, T. Rojano, \& A. Sepulveda (Eds.), Proceedings of the joint meeting of Pme 32 and Pme-Na Xxx, Vol 3 (pp.169-176). Mexico: Cinvestav-UMSNH.

Kasmer, L., \& Kim, O. K. (2011). Using prediction to promote mathematical understanding and reasoning. School Science and Mathematics, 111(1), 20-33. https://doi.org/10.1111/j.1949-8594.2010.00056.x

Kazakoff, E. R., Sullivan, A., \& Bers, M. U. (2013). The effect of a classroom-based intensive robotics and programming workshop on sequencing ability in early childhood. Early Childhood Education Journal, 41(4), 245-255. https://doi.org/10.1007/s10643-012-0554-5

Keazer, L. M., \& Menon, R. S. (2016). Reasoning and sense making begins with the teacher. Mathematics Teacher, 109(5), 342-349. https://doi.org/10.5951/mathteacher.109.5.0342

Kynigos, C. (1993). Children's inductive thinking during intrinsic and Euclidean geometrical activities in a computer programming environment. Educational Studies in Mathematics, 24(2), 177-197. https://doi.org/10.1007/BF01273691

Morgado, L., Cruz, M., \& Kahn, K. (2010). Preschool cookbook of computer programming topics. Australasian Journal of Educational Technology, 26(3), 309-326. https://doi.org/10.14742/ajet.1077

Mullis, I. V., Martin, M. O., \& Foy, P. (2005). IEA's TIMSS 2003 International report on achievement in the mathematics cognitive domains: findings from a developmental project. TIMSS \& PIRLS International Study Center.

Nance, S. E. (2016). Using computer programming to enhance problem-solving skills of fifth grade students. (Unpublished doctoral dissertation). University of Florida. https://ufdc.ufl.edu/UFE0050247/ 00001

National Council of Teachers of Mathematics (NCTM). (2000). Principles and standards for school mathematics. National Council of Teachers of Mathematics. 
National Research Council. (2009). Mathematics learning in early childhood: Paths toward excellence and equity. The National Academies Press.

Olteanu, C. (2020). Programming, mathematical reasoning and sense-making. International Journal of Mathematical Education in Science and Technology, 1-19. https://doi.org/10.1080/0020739X.2020. 1858199

Paulos, J. A. (1995). A mathematician reads the newspaper: Making sense of the numbers in the headlines. Penguin Books.

Perry, B., \& Dockett, S. (2008). Young children's access to powerful mathematical ideas. In L. D. English (Ed.), Handbook of international research in mathematics education (pp. 75-108). Routledge.

Pilten, P. (2008). Ustbiliş stratejileri öğretiminin ilköğretim beşinci sinıf öğrencilerinin matematiksel muhakeme becerilerine etkisi. (Unpublished doctoral dissertation). Gazi University, Ankara.

Psycharis, S., \& Kallia, M. (2017). The effects of computer programming on high school students' reasoning skills and mathematical self-efficacy and problem solving. Instructional Science, 45(5), 583602. https://doi.org/10.1007/s11251-017-9421-5

Resnick, M. (2003). Playful learning and creative societies. Education Update, 1-2.

Rule, A. C. (2007). Mystery boxes: Helping children improve their reasoning. Early Childhood Education Journal, 35(1), 13-18. https://doi.org/10.1007/s10643-007-0156-9

Taylor, M., Harlow, A., \& Forret, M. (2010). Using a computer programming environment and an interactive white board to investigate some mathematical thinking. Procedia-Social and Behavioral Sciences, 8, 561-570. https://doi.org/10.1016/j.sbspro.2010.12.078

Toh, L. P. E.,Causo, A., Tzuo, P. W., Chen, I. M., \& Yeo, S. H. (2016). A review on the use of robots in education and young children. Journal of Educational Technology \& Society, 19(2), 148-163. http:// www.jstor.org/stable/jeductechsoci.19.2.148

Turan, S., \& Aydoğdu, F. (2020). Effect of coding and robotic education on pre-school children's skills of scientific process. Education and Information Technologies, 25(5), 4353-4363. https://doi.org/10. 1007/s10639-020-10178-4

Umay, A. (2003). Matematiksel muhakeme yeteneği. Hacettepe Üniversitesi Ĕ̆itim Fakültesi Dergisi, 24(24), 234-243.

Umay, A., \& Kaf, Y. (2005). Matematikte kusurlu akıl yürütme üzerine bir çalışma. Hacettepe Üniversitesi Ĕ̆itim Fakültesi Dergisi, 28, 188-195.

Yünkül, E., Durak, G., Çankaya, S., \& Mısırlı, Z. A. (2017). Scratch yazılımının öğrencilerin bilgisayarca düşünme becerilerine etkisi. Necatibey Eğitim Fakültesi Elektronik Fen ve Matematik Eğitimi Dergisi, 11(2), 502-517. https://doi.org/10.17522/balikesirnef.373424

Whittaker, J. V. (2014). Good thinking! Fostering young children's reasoning and problem solving. Young Children, 69, 80-89. https://www.jstor.org/stable/ycyoungchildren.69.3.80

Publisher's Note Springer Nature remains neutral with regard to jurisdictional claims in published maps and institutional affiliations. 